\title{
Teaching a Business Honors Course on China
}

\author{
Patricia Matisz Smith \\ North Carolina Wesleyan College
}

This paper describes an honors course on China taught over several years with evolving overarching topics. The objective of the course was to explore the economic and developmental path China has taken to engage with the world. Readings included current authors who have experienced life in China. Emphasis was placed on student-led discussion, writing, critical thinking, and oral presentation about the country and its emergence to interact with the rest of the world.

Keywords: China, Honors Course, Active Learning

\section{INTRODUCTION}

The honors program is offered to students with any major at North Carolina Wesleyan College. During the sophomore and junior years, students complete twelve semester hours of specially designed honors courses. Additionally, during the senior year, Honors Program students complete an interdisciplinary project where students work on an individual basis with a director and faculty committee to complete a research or creative project. Graduating seniors who participate in the program receive special recognition on the diploma, honors status is announced at graduation, and an honors cord is worn

The honors program director and program committee have selected my course for the sophomore/junior selection over the past six two-year cycles. I have adjusted the emphasis as I developed materials. In addition, I was able to participate in the Centers for International Business Education and Research (CIBER) Faculty Development in International Business (FDIB) travel/education to China with the University of Colorado, Denver for additional source material.

List of honors courses taught:

2005 Globalization

2010, 2012, 2014 China: An Emerged Global Powerhouse

2016 China: Opportunities and Challenges

2018 China: One Belt One Road 一带一路

Undergraduate sophomore and junior students taking BUS 495H China come from a variety of majors and have not had a previous course on China. I designed the courses with three components, introductory readings for background on China, articles with current topics from the business press and elsewhere, and finally a contemporary trade book on China.

AACSB guidelines state that student learning should be active rather than passive, with learning that involves students in engaging and challenging activities. This honors course emphasizes these approaches. The most effective learning takes place when students are involved in their educational experiences. "Curricula facilitate and encourage active student engagement in learning. In addition to time on task related to readings, course participation, knowledge development, projects, and assignments, 
students engage in experiential and active learning designed to be inclusive for diverse students, and to improve skills and the application of knowledge in practice." At Wesleyan, the general education program goals include critical thinking, writing, and oral presentation skills. Each of these was included in my honors courses.

The guidelines further state "Passive learning is ineffective and of short duration. Faculty members should develop techniques and styles that engage students and make students responsible for meeting learning goals. Many pedagogical approaches are suitable for challenging students in this way - problembased learning, projects, simulations, etc. Faculty members should find such approaches that are suited to their subject matter, and should adopt active learning methodologies". (Eligibility procedures AACSB, 2018).

\section{ORGANIZATION OF ACTIVITIES AND READINGS}

Each course began with readings from China: Global Studies. This book is one of McGraw Hill's Global Studies series and includes current articles, maps, and statistics. The first of many required readings was "People's Republic of China Country Report." The report begins with a historical overview beginning around $5000 \mathrm{BCE}$ and continues to topics of the present. The chapter includes sections on Mao Zedong, Red Guards, Pinyin, among other topics. The Special Economic Zones (SEZ) and the mixed economy, legal system, and political systems are also covered. I also assigned the Country Report (sic) on Hong Kong. In addition to the history, this section included a discussion of the status of Hong Kong. Hong Kong as a world trade and financial center and the future were emphasized. I did not assign the Country Report on Taiwan which was also included in the book.

Selections from James Fallows' Postcards from Tomorrow Square and other recent articles comprised the second component of the course. Fallows was the national correspondent for The Atlantic. This book is the result of his living in and reporting from China. In course feedback, students report reading $100 \%$ of the required parts of this book. I developed a course pack that included the most current reports and news from the business press and international reporting. In 2018 this included thirteen readings on the theme topic with recent publication dates.

It was difficult to decide how to teach material originating from articles or trade books as opposed to textbooks. I decided on a daily handout containing a brief outline of the reading; several objective questions from the reading; a Bloom's taxonomy higher-order discussion question; and at least one definition of interesting vocabulary. I prepared and presented the first few for the class and asked each of the students in the class to select a reading of their own to present. One comment in the student evaluation question "What did you enjoy most about this course?" "The teaching style. How the teacher let the students teach the material and she also taught the parts that were hard for the students to grasp." Examples of class handouts are included in this paper reproduced with the students' permission.

Although his writing in The Atlantic is fascinating, I found some of Fallows' work very difficult to teach. The articles, when read in a magazine, are cogent but when making an attempt to pin down his primary theme for a class, I found that many of his articles contain too wide a range of topics. At times he even contradicts himself. The more scholarly business-related articles in the Global Studies book, The Economist, etc. were easier to teach in this regard. However, Fallows' article "The \$1.4 Trillion Question" is perhaps the best explanation of the interaction between the renminbi, trade, China's economic policy, and the dollar that anyone can read.

Fallows also has published a series of videos based on the book called "Doing Business in China" We also purchased video called "Convenience Store Wars", and borrowed the Fallows DVDs on interlibrary loan. Students continuously referred to these videos in our discussions and even in their papers. It turns out that honors students are also visual learners. Responses to the course feedback question "Do you have a comment on the videos?" included: "It was very interesting to get to see real Chinese citizens' views on Chinese business." "The videos were quite interesting. The Chinese love of low-end American culture is amusing, especially the "trendy" Pizza Hut". I also showed the documentary Last Train Home which is a heartbreaking documentary about migrant workers in China. This video made a huge impression on students every time I showed it. Many continued to refer to it in later discussions and writing. 
The third component to the course was the student reading circle selections, a complete list is available at the end of this paper as "Reading Circle Options". Student selections reflected their interests and majors. For example Vermeer's Hat tended to be selected by history majors; River Town for science majors; Factory Girls women and/or sociology majors; and One Billion Customers and Age of Ambition by business majors. Students produced a written report and made a final presentation to the class. The written report was in the form of a question-answer on topics addressed by the book. After the question and answer section, teams added a vocabulary section of three or four *interesting* words and an appendix of important topics to further understanding. The papers used APA format and cited our two common books and articles as needed.

Reading circle groups consisted of two to three students. I was a little disappointed that the several of my favorite books were never chosen. In course feedback, about half students reported that they are "very likely" or are "somewhat likely" to read another book from our class in the future.

One paper that was the most surprising to me was written by the reading circle on Factory Girls comprised of women students. This book discusses the extremely difficult lives of the very young women who work in these factories. They leave their families for years at a time to work in cities of perhaps 50,000,000 people. I had assumed that American college students would feel empathy with these young people. Instead the main analysis theme that one team wrote about was "deception and lying". The factory girls often use identification of an older sibling or other acquired identification to be legal to work. They make up experience and resume items. However, the author, Chang emphasizes their longing to improve themselves by learning English, computers, and general business knowledge.

Each team prepared a power point to present to the class along with a summary of the book. The groups' work included pictures and video clips of author interviews. I always included requirements for non-presenters to answer questions or prepare written notes from their fellow students' presentations. Even honors students will drift away from presentations unless there is some "skin in the game"!

The final component consisted of two in-class writing assignments completed in a computer classroom. These were open-book and open-notes response to essay questions. Questions emphasized higher-order Bloom's taxonomy, analysis, synthesis, and evaluation.

\section{CONCLUSION}

This has been a very enjoyable class to teach over the years. It is such a timely topic that students recognize the relevance of the material and continued to be engaged. Although the course was listed as a business class, we spent considerable effort in reviewing the history, culture, and current state of the government and politics of China. I made special effort to insure that business topics had adequate coverage for non-business majors. Topics included capital formation, legal ownership, foreign exchange, and labor laws.

Students appreciated the active learning aspect of these courses. They liked having control over choice of topics and readings. I noticed many occasions when student teams expressed outstanding creativity in their presentations and exceptional understanding of the concepts.

\section{PERSONAL NOTE}

During a 1975 visit to Hong Kong I took a tour and fell asleep on the bus. We stopped and got off the bus in an empty parking lot near a small dip in the land with a tree-covered hill a short distance away. The guide pointed at the trees and said "That is China".

\section{REFERENCE}

Eligibility Procedures and Accreditation Standards for Business Accreditation, Revised. (2018). Retrieved from https://www.aacsb.edu/-/media/aacsb/docs/accreditation/business/standards-andtables/2018-businessstandards.ashx?la=en\&hash=B9AF18F3FA0DF19B352B605CBCE17959E32445D9 


\section{APPENDIX 1}

\section{Questions prepared by an Honors Program student Presented with student's permission \\ Postcards: The \$1.4 Trillion Question, p. 144 - 168}

China has over $\$ 1.4$ trillion in trade surplus, and this amount grows by $\$ 1$ billion per day. Most of the surplus is in U.S. Treasury notes. The problem is, the dollar is continually weakening and some Chinese think the surplus should be put into a stronger currency. So the question is what will China do with its $\$ 1.4$ trillion surplus?

1. By putting $\$ 3$ billion of China's national savings into the initial public offering of America's best-known private-equity firm, the Chinese government itself with a big-time Western firm without raising political fears by trying to buy

(It bought only 8 percent of Blackstone's shares, and they were nonvoting shares.)

2. Through the quarter century in which China has been opening to world trade, Chinese leaders have deliberately held down for their own people and propped them up in the

3. Any economist will say that Americans have been better that they should.

4. In the article published in the July/August 2005 issue of , Fallows described an imagined future in which a realestate crash and shakiness in the U.S. credit markets led to panic by Chinese and other foreign investors, with unpleasant effects for years to come.

5. In China, they must treat the dollars as , and turn most or all of them over to

China's equivalent of the Federal Reserve Bank, , for RMB.

6. The bargain China has made is that they'll keep creating new factory jobs, and thus reduce China's own and create opportunities for its The Chinese will live better year by year, though

Discussion Question: What do you think China may be doing with its $\$ 1.4$ trillion surplus and why do you think they keep the bulk of it in U.S. dollars?

Word of the Day: Laobaixing - ordinary folks; old hundred surnames; the common people of China. [http://en.wikipedia.org/wiki/Chinese_surname] 


\section{APPENDIX 2}

\section{Questions prepared by an Honors Program student Presented with student's permission Article 10 “China's Factory Blues" p.118-120}

Manufacturers are discovering that China's low labor costs and easy regulations are ending. New labor laws, as well as increases in commodity and energy prices, have caused export prices to rise. Small companies in Guangdong, China have been forced to shut down, leaving many people without jobs or money. Manufacturers who relocate to Vietnam or India still face increasing labor costs and supply shortages. In order to keep prices down, manufacturers search for other cities in China that has lower labor costs than the South. After all, "the answer to high prices in China is more China."

1. The Pearl River Delta region of ___ is the largest manufacturing base in the world.

2. The U.S.___ market has plummeted, causing little demand for Chinese-made bedroom sets and bathroom fixtures.

3. The federation of Hong Kong Industries predicts ___ percent of factories in the Delta region will close.

4. In order to boost domestic consumption, Beijing wants industries that make high quality products.

5. Over__ percent of foreign manufacturers in China think that the mainland is losing its competitive advantage over India and Vietnam.

6. The new labor law requires companies to provide employee benefits including

7. While it costs $1000 \mathrm{RMB}$ per month per unskilled worker in China, it only costs $500 \mathrm{RMB}$ per month in

8. India has strict specifications on materials used to build factories.

9. In an attempt to raise efficiency, some manufacturers are trying

10. Manufacturers are also reducing employee since it nears $75 \%$ in China.

Explain why China is losing its competitive advantage over Vietnam and India. What are some advantages and disadvantages of relocating out of China? 


\section{APPENDIX 3}

\section{BUS 495H China an Emerged Economic Powerhouse \\ Dr. Smith -Notes for March 19, 2010 \\ Postcards p. 66-105 China Makes the World Takes}

James Fallows quotes an American industrial designer in China "People are the most adaptable machines... Machines need to be reprogrammed. You can have people doing something entirely different next week." He describes American companies that have designed shipping and fulfillment in Shenzhen that ship directly to specific retail stores in America.

\section{Multiple Choice:}

1. Number of people in China who work in factories:
a. 100 million
b. 500 million
c. 750 million

2. Breakfast at the Sheraton Four Points in Shenzhen:
a. Sliced meats, cheese, breads for Europeans
b. Pickles, sushi, noodles for Japanese
c. Dim sum, congee, steamed buns for Chinese
d. Denny's style slam for Americans
e. All of the above

3. Fallows believes that:
a. America should tighten Visa rules for foreigners
b. America has an advantage by absorbing world's talent

4. Chinese workers go home for:
a. Christmas
b. Valentine's day
c. Spring Festival

5. After liberalization entrepreneurs flocked to Shenzhen from :
b. Taiwan
c. Russia

6. The buyers and suppliers in Shenzhen obsess about:
a. Making jokes
b. Eating
c. Keeping secrets

7. Wish to minimize association with outsourcing is known as the:
a. The Nike problem
b. The Coffee problem
c. Growth rate
d. All of the above

8. Ford Motor's plant in Detroit is called:
a. Lockheed
b. Honeywell
c. River Rouge Works

9. The "smiley curve" shows profitability or value added at each stage. Which statement is correct?
a. Retail and servicing stages are at the bottom of the curve
b. Manufacturing is at the bottom of the curve
c. Branding and product concept stage is at the bottom.

a. South Africa 
Americans may be uncomfortable with the way America is being shaped by global economic forces. How are trends in borrowing, consuming, looking inward, using infrastructure make it hard for America to stay ahead of China? Do the solutions to the problems lie on the side of China or America?

con·ur·ba·tion Pronunciation: \,k̈̈-(,)nər-'bā-shən\Function: noun. Etymology: com- + Latin urb-, urbs city. Date: 1915. : an aggregation or continuous network of urban communities

Reference

conurbation (2010) Merriam-Webster's Collegiate Dictionary. Retrieved on March 12, 2010 from The Merriam-Webster Online Dictionary http://www.merriam-webster.com/dictionary/conurbation

\section{APPENDIX 4}

\section{READING CIRCLE OPTIONS}

Brook, T. (2008). Vermeer's hat: The seventeenth century and the dawn of the global world (1st U.S. ed.). New York: Bloomsbury Press: Distributed to the trade by Macmillan.

Chang, L. T. (2008). Factory girls: From village to city in a changing China (1st ed.). New York: Spiegel \& Grau.

Clavell, J. (1983). James Clavell's Tai-Pan. New York: Delacorte Press.

Fallows, D. (2010) Dreaming in Chinese: Mandarin lessons in life, love, and language. New York, NY: Walker \& Co.

Gifford, R. (2008). China road: A journey into the future of a rising power (Random House Trade Paperback ed.). New York: Random House Trade Paperbacks.

Hessler, P. (2001). River town: two years on the Yangtze (1st ed.). New York: HarperCollins Publishers.

McGregor, J. (2006). One billion customers: Lessons from the front lines of doing business in China. New York: Free Press.

Meyer, M. (2015) In Manchuria: A village called Wasteland and the transformation of rural China. New York: Bloomsbury Press.

Osnos, E. (2014). Age of ambition: Chasing fortune, truth, and faith in the new China. New York: Farrar, Straus and Giroux

Pomfret, J. (2006). Chinese lessons: Five classmates and the story of the new China (1st ed.). New York: H. Holt.

Schell, O. \& Delury, J. (2013) Wealth and power: China's long march to the twenty-first century. New York: The Random House Publishing Group

Wasserstrom, J. N. (2007). China's brave new world: and other tales for global times. Bloomington: Indiana University Press.

Zhu, Z. (2010) Global Studies: China. Boston: McGraw Hill Higher Education (ISBN 978-0-07337987-5) 